\title{
The Isolation and Characterization of Molecular Complexes Produced from the Reaction of Nitrophenols with Divalent Metal Oxinates
}

\author{
M. M. Aly \\ Chemistry Department, Faculty of Science, Assiut University, Assiut, Egypt \\ and
}

\author{
A. M. Shalaby \\ Chemistry Department, Faculty of Science, El-Mansoura University, El-Mansoura, Egypt
}

Z. Naturforsch. 34 b, 230-234 (1979); received July 31, 1978

Nitrophenols, Divalent Metal Oxinates, Molecular Complexes

The reaction of nitrophenols (picric acid, 2,6-dinitrophenol, and 2,4-dinitrophenol) with divalent metal oxinate (metal $=\mathrm{Cu}, \mathrm{Co}, \mathrm{Ni}, \mathrm{Mn}$, and $\mathrm{Zn}$ ) produced a type of molecular complex, which comprises two molecules of the metal oxinate and one molecule of the nitrophenol. In the case of the $\mathrm{Mg}$ complex the ratio is 1:1. A definite charge-transfer band is detected for the $\mathrm{Co}(\mathrm{II})$ complex. A hydrogen bonding system $\mathrm{O}_{1} \ldots \mathrm{H}^{+} \ldots \mathrm{O}_{2}$ is suggested. This includes the proton of the nitrophenol and two oxygen atoms; each is related to a coordinated oxinate of two different metal oxinate molecules. Analytical and spectral evidence are in accordance with the tentatively suggested formulations.

\section{Introduction}

Molecular complexes of a variety of organic electron donor and acceptor molecules have been reviewed by Briegleb [1]. The donor behaviour of the oxine ligand was investigated with several organic electron acceptors [2,3]. Moreover, the divalent copper, palladium, and nickel oxinates formed molecular complexes with typical organic electron acceptors [3]. The stoichiometry of the molecular complexes shows that the donor: acceptor ratio is independent of the metal. Ratios of one copper(II) oxinate to either one acceptor (e.g. trinitrofluorenone, chloranil) or two acceptors (e.g. trinitrobenzene, picryl azide) were reported [3]. The crystal structures of some of these molecular complexes were determined [4-7]. We wish to report the reactions of some metal oxinates with dinitro- and trinitrophenols. Interest in these nitrophenols stems from the fact that they combine the electron acceptor aromatic nitrophenol and the acidic proton which is known to attack the metal-nitrogen bond of the chelate ring in the metal oxinate [8].

\section{Experimental}

Reagent grade chemicals were used. The metal oxinates were prepared as described [9] earlier ( $\alpha$ form of $\mathrm{Cu}$ (II) oxinate was used). Solvents were spectra grade. The electronic spectra were recorded

Requests for reprints should be sent to Dr. M. M. Aly, Chemistry Department, Faculty of Science, Assiut University, Assiut, Egypten.

$0340-5087 / 79 / 0200-0230 / \$ 01.00 / 0$ with a Unicam SP 8000 spectrophotometer. The infrared spectra of the metal complexes were measured as nujol mulls using a Perkin-Elmer 577 Grating Infracord (4000-200 $\left.\mathrm{cm}^{-1}\right)$. Carbon, hydrogen were determined at Dr. F. B. Strauss microanalytical laboratory. Standard methods were used for the metal analysis. The separated complexes were dried under vacuum over phosphorus pentoxide.

The reaction between the metal oxinates $\mathrm{MOx}_{2}$ $(\mathrm{M}=$ divalent $\mathrm{Cu}, \mathrm{Co}, \mathrm{Ni}, \mathrm{Mn}, \mathrm{Zn}$, and $\mathrm{Mg}$ ) and nitrophenols (picric acid, 2,6-dinitrophenol, and 2,4-dinitrophenol) was carried out as follows. The benzene solution $(100 \mathrm{ml})$ of the nitrophenol (0.006 moles) was added to the powdered metal oxinate $(0.006$ moles). The resulting reaction mixture was refluxed for $1 \mathrm{~h}$. The precipitated complex was filtered from the warm solution, washed with benzene, and dried.

The metal complexes were incompletely soluble in chloroform, insoluble in other organic solvents, and decompose in water to the nitrophenol and the metal oxinate.

\section{Results and Discussion}

The cleavage of the $\mathrm{M}-\mathrm{N}$ bond of the chelate ring of the metal oxinates and the subsequent protonation of the quinoline nitrogen by the action of haloacetic acids produced an oxine molecule coordinated to the metal atom, as a zwitterion molecule, via its phenolate oxygen [8]. The dinitroand trinitrophenols provided a type of molecule which has not only the acidic proton, though a weak acid, but also the nitroaromatic characteristic of the $\pi$-electron acceptor. 
Table I. Suggested formulations, elemental analyses, colour, and effect of heat for the metal complexes. (Hpic, H 2,6-ph, and $\mathrm{H}$ 2,4-ph refer to picric acid, and 2,6-, and 2,4-dinitrophenol respectively).

\begin{tabular}{|c|c|c|c|c|c|c|c|c|}
\hline Number & $\begin{array}{l}\text { Suggested formulation } \\
\text { (C) = Calculated, } \\
\text { (F) = Found }\end{array}$ & & $\begin{array}{l}\text { Eleme } \\
\text { C }\end{array}$ & $\mathrm{H}$ & $\begin{array}{l}\text { yses }[\%] \\
\mathrm{N}\end{array}$ & Metal & Colour & $\begin{array}{l}\text { Effect of heat } \\
{\left[{ }^{\circ} \mathrm{C}\right]}\end{array}$ \\
\hline $\mathbf{1}$ & $\begin{array}{l}\left(\mathrm{CuOx}_{2}\right)_{2} \mathrm{Hpic} \\
\mathrm{C}_{42} \mathrm{H}_{27} \mathrm{~N}_{7} \mathrm{O}_{11} \mathrm{Cu}_{2}\end{array}$ & $\begin{array}{l}(\mathrm{C}) \\
(\mathrm{F})\end{array}$ & $\begin{array}{l}54.08 \\
53.71\end{array}$ & $\begin{array}{l}2.92 \\
3.12\end{array}$ & $\begin{array}{l}10.51 \\
10.22\end{array}$ & $\begin{array}{l}13.62 \\
13.90\end{array}$ & $\begin{array}{l}\text { greenish- } \\
\text { yellow }\end{array}$ & $\begin{array}{l}\text { changes to brown } \\
\text { at } 260\end{array}$ \\
\hline 2 & $\begin{array}{l}\left(\mathrm{NiOx}_{2}\right)_{2} \mathrm{Hpic} \\
\mathrm{C}_{42} \mathrm{H}_{27} \mathrm{~N}_{7} \mathrm{O}_{11} \mathrm{Ni}_{2}\end{array}$ & $\begin{array}{l}\text { (C) } \\
\text { (F) }\end{array}$ & $\begin{array}{l}54.65 \\
54.96\end{array}$ & $\begin{array}{l}2.95 \\
3.23\end{array}$ & $\begin{array}{l}10.62 \\
10.81\end{array}$ & $\begin{array}{l}12.76 \\
12.34\end{array}$ & $\begin{array}{l}\text { greenish- } \\
\text { yellow }\end{array}$ & $\begin{array}{l}\text { changes to dark } \\
\text { brown at, } 300\end{array}$ \\
\hline $\mathbf{3}$ & $\begin{array}{l}\left(\mathrm{MnOx}_{2}\right)_{2} \mathrm{Hpic} \\
\mathrm{C}_{42} \mathrm{H}_{27} \mathrm{~N}_{7} \mathrm{O}_{11} \mathrm{Mn}_{2}\end{array}$ & $\begin{array}{l}\text { (C) } \\
(\mathrm{F})\end{array}$ & $\begin{array}{l}55.10 \\
55.41\end{array}$ & $\begin{array}{l}2.97 \\
3.18\end{array}$ & $\begin{array}{l}10.71 \\
10.42\end{array}$ & $\begin{array}{l}12.81 \\
13.17\end{array}$ & $\begin{array}{l}\text { yellowish- } \\
\text { brown }\end{array}$ & $\begin{array}{l}\text { changes to brown } \\
\text { at } 290\end{array}$ \\
\hline 4 & $\begin{array}{l}\left(\mathrm{ZnOx}_{2}\right)_{2} \mathrm{Hpic} \\
\mathrm{C}_{42} \mathrm{H}_{27} \mathrm{~N}_{7} \mathrm{O}_{11} \mathrm{Zn}_{2}\end{array}$ & $\begin{array}{l}\text { (C) } \\
\text { (F) }\end{array}$ & $\begin{array}{l}53.81 \\
53.46\end{array}$ & $\begin{array}{l}2.90 \\
3.05\end{array}$ & $\begin{array}{l}10.46 \\
10.33\end{array}$ & $\begin{array}{l}14.05 \\
14.29\end{array}$ & yellow & $\begin{array}{l}\text { changes to brown } \\
\text { at } 235\end{array}$ \\
\hline 5 & $\begin{array}{l}\mathrm{MgOx}_{2} \mathrm{Hpic} \\
\mathrm{C}_{24} \mathrm{H}_{15} \mathrm{~N}_{5} \mathrm{O}_{9} \mathrm{Mg}\end{array}$ & $\begin{array}{l}\text { (C) } \\
\text { (F) }\end{array}$ & $\begin{array}{l}53.21 \\
53.56\end{array}$ & $\begin{array}{l}2.79 \\
3.00\end{array}$ & $\begin{array}{l}12.93 \\
12.56\end{array}$ & $\begin{array}{l}4.49 \\
4.63\end{array}$ & yellow & melts at 205 \\
\hline 6 & $\begin{array}{l}\left(\mathrm{CoOx}_{2}\right)_{2} \mathrm{H} 2,6-\mathrm{ph} \\
\mathrm{C}_{42} \mathrm{H}_{28} \mathrm{~N}_{6} \mathrm{O}_{9} \mathrm{Co}_{2}\end{array}$ & $\begin{array}{l}\text { (C) } \\
(\mathrm{F})\end{array}$ & $\begin{array}{l}57.42 \\
57.78\end{array}$ & $\begin{array}{l}3.21 \\
3.30\end{array}$ & $\begin{array}{l}9.57 \\
9.34\end{array}$ & $\begin{array}{l}13.42 \\
13.77\end{array}$ & red & $\begin{array}{l}\text { changes to brown } \\
\text { at } 300\end{array}$ \\
\hline 7 & $\begin{array}{l}\left(\mathrm{NiOx}_{2}\right)_{2} \mathrm{H} 2,6-\mathrm{ph} \\
\mathrm{C}_{42} \mathrm{H}_{28} \mathrm{~N}_{6} \mathrm{O}_{9} \mathrm{Ni}_{2}\end{array}$ & $\begin{array}{l}\text { (C) } \\
\text { (F) }\end{array}$ & $\begin{array}{l}\mathbf{5 7 . 4 5} \\
\mathbf{5 7 . 8 0}\end{array}$ & $\begin{array}{l}3.21 \\
3.31\end{array}$ & $\begin{array}{l}9.57 \\
9.34\end{array}$ & $\begin{array}{l}13.37 \\
13.03\end{array}$ & brown & $\begin{array}{l}\text { changes to black } \\
\text { at } 210\end{array}$ \\
\hline 8 & $\begin{array}{l}\left(\mathrm{CuOx}_{2}\right)_{2} \mathrm{H} 2,4-\mathrm{ph} \\
\mathrm{C}_{42} \mathrm{H}_{28} \mathrm{~N}_{6} \mathrm{O}_{9} \mathrm{Cu}_{2}\end{array}$ & $\begin{array}{l}\text { (C) } \\
\text { (F) }\end{array}$ & $\begin{array}{l}56.82 \\
57.04\end{array}$ & $\begin{array}{l}3.18 \\
3.19\end{array}$ & $\begin{array}{l}9.47 \\
9.45\end{array}$ & $\begin{array}{l}14.31 \\
14.05\end{array}$ & green & $\begin{array}{l}\text { changes to brown } \\
\text { at } 260\end{array}$ \\
\hline 9 & $\begin{array}{l}\left(\mathrm{NiOx}_{2}\right)_{2} \mathrm{H}_{2}, 4-\mathrm{ph} \\
\mathrm{C}_{42} \mathrm{H}_{28} \mathrm{~N}_{6} \mathrm{O}_{9} \mathrm{Ni}_{2}\end{array}$ & $\begin{array}{l}\text { (C) } \\
\text { (F) }\end{array}$ & $\begin{array}{l}57.45 \\
57.11\end{array}$ & $\begin{array}{l}3.21 \\
3.35\end{array}$ & $\begin{array}{l}9.57 \\
9.29\end{array}$ & $\begin{array}{l}13.37 \\
13.62\end{array}$ & brown & $\begin{array}{l}\text { changes to black } \\
\text { at } 255\end{array}$ \\
\hline 10 & $\begin{array}{l}\left(\mathrm{MnOx}_{2}\right)_{2} \mathrm{H} 2,4-\mathrm{ph} \\
\mathrm{C}_{42} \mathrm{H}_{28} \mathrm{~N}_{6} \mathrm{O}_{9} \mathrm{Mn}_{2}\end{array}$ & $\begin{array}{l}\text { (C) } \\
\text { (F) }\end{array}$ & $\begin{array}{l}57.94 \\
58.31\end{array}$ & $\begin{array}{l}3.24 \\
3.41\end{array}$ & $\begin{array}{l}9.65 \\
9.60\end{array}$ & $\begin{array}{l}12.62 \\
12.89\end{array}$ & brown & $\begin{array}{l}\text { changes to black } \\
\text { at } 330\end{array}$ \\
\hline 11 & $\begin{array}{l}\left(\mathrm{ZnOx}_{2}\right)_{2} \mathrm{H} 2,4-\mathrm{ph} \\
\mathrm{C}_{42} \mathrm{H}_{28} \mathrm{~N}_{6} \mathrm{O}_{9} \mathrm{Zn}_{2}\end{array}$ & $\begin{array}{l}\text { (C) } \\
\text { (F) }\end{array}$ & $\begin{array}{l}56.59 \\
56.74\end{array}$ & $\begin{array}{l}3.17 \\
3.40\end{array}$ & $\begin{array}{l}9.43 \\
9.17\end{array}$ & $\begin{array}{l}14.67 \\
14.91\end{array}$ & yellow & $\begin{array}{l}\text { changes to brown } \\
\text { at } 230\end{array}$ \\
\hline
\end{tabular}

The analytical data in Table I are compatible with the reaction

$$
\begin{aligned}
& 2 \mathrm{MOx}_{2}+\text { nitrophenol } \rightarrow\left(\mathrm{MOx}_{2}\right)_{2} \text { nitrophenol } \\
& \mathrm{M}=\text { divalent } \mathrm{Cu}, \mathrm{Co}, \mathrm{Ni}, \mathrm{Mn} \text { or } \mathrm{Zn} \text {; nitro- } \\
& \text { phenol = picric acid, 2,6-dinitrophenol, or 2,4- } \\
& \text { dinitrophenol. }
\end{aligned}
$$

This reaction is applicable for all compounds in Table I except for compound 5, which was obtained from the reaction of picric acid with $\mathrm{MgOx}_{2}$, where the stoichiometry of the compound is one $\mathrm{Mg}$ oxinate to one picric acid. The reaction of nitrophenols with the metal oxinate is expected to be influenced by the $\mathrm{pK}$ of the nitrophenol, the stability of the M-N and $\mathrm{M}-\mathrm{O}$ bonds of the oxinate chelate ring, and by the ability of the metal oxinate to form a stable molecular complex with the nitrophenol. Accordingly, the investigated points are (i) breaking of either the M-N or the M-O bond, and possibly both (ii) the appearance of a charge-transfer band where neither the metal oxinate (donor) nor the nitrophenol (acceptor) absorb, and (iii) the effect of the formed structure on the vibrations of the metal oxinate and the nitrophenol.
The infrared spectra of compounds 1-11 listed in Table II do not reveal any vibrational bands attributable to either the $+\mathrm{N}-\mathrm{H}$ stretching $(3200$ to $3400 \mathrm{~cm}^{-1}$ ) or the composite bands of the $+\mathrm{N}-\mathrm{H} \cdots \mathrm{O}$ system (2050 and $2650 \mathrm{~cm}^{-1}$ similar to those of the oxine adduct of $\mathrm{Th}(\mathrm{IV})$ and $\mathrm{U}(\mathrm{VI})$ oxinates $[10,11])$. However, the vibrational features of these complexes reveal (a) shifts of $v \mathrm{~N}-\mathrm{O}_{\text {asym }}, v \mathrm{~N}-\mathrm{O}_{\text {sym }}$ of the nitrogroup and $v \mathrm{C}-\mathrm{N}$ from their locations in the nitrophenol [12], Table II, (b) the disappearance of $\delta \mathrm{O}-\mathrm{H}$ of the nitrophenol (normally observed [12] at $1150 \mathrm{~cm}^{-1}$ ) (c) splitting of the $v \mathrm{C}-\mathrm{O}$ [13], and the in-plane $\mathrm{C}-\mathrm{O}$ bending $[14,15]$ into two bands (Table II) while the position of the chelate ring deformation band was not significantly changed, and (d) the appearance of weak bands in the 1700-2000 $\mathrm{cm}^{-1}$ region; see Table III. These observations are in accordance with the assumption that the association of the two metal oxinate molecules with the nitrophenol molecule is through a hydrogen bonding formation that combines the hydrogen of the phenolic hydroxyl and the oxygens of two bidentate oxinate ions (one from each metal oxinate, see Fig. 1). This situation is evidenced by 
Table II. Vibrational features $\left[\mathrm{cm}^{-1}\right]$ of metal complexes; Nujol mull.

\begin{tabular}{|c|c|c|c|c|c|c|}
\hline Complex & $\begin{array}{l}\text { Nitrophenol } \\
\nu \mathrm{N}-\mathrm{O}_{\text {asym }} \\
\mathrm{a}\end{array}$ & $\begin{array}{l}v \mathrm{~N}-\mathrm{O}_{\mathrm{sym}} \\
\mathrm{b}\end{array}$ & $\begin{array}{l}\text { Assignment } \\
v \mathrm{C}-\mathrm{N} \\
\mathrm{c}\end{array}$ & $\begin{array}{l}\text { Metal oxinate } \\
\nu \mathrm{C}-\mathrm{O} \\
\text { d }\end{array}$ & $\begin{array}{l}\text { in-plane } \\
\text { C-O bend } \\
\text { e }\end{array}$ & $\begin{array}{l}\text { chelate } \\
\text { ring def. } \\
\text { f }\end{array}$ \\
\hline 1 & $\begin{array}{l}1562(\mathrm{w}), 1542(\mathrm{w}) \\
1537(\mathrm{~m})\end{array}$ & $1350(\mathrm{~m})$ & $837(\mathrm{~m})$ & $\begin{array}{l}1118(\mathrm{~m}) \\
1113(\mathrm{~s})\end{array}$ & $\begin{array}{l}522(\mathrm{~m}) \\
515(\mathrm{w})\end{array}$ & $408(\mathrm{~m})$ \\
\hline 2 & $\begin{array}{l}1560(\mathrm{w}), 1545(\mathrm{w}) \\
1535(\mathrm{~m})\end{array}$ & $1360(\mathrm{~m})$ & $846(w)$ & $\begin{array}{l}1117(\mathrm{~s}) \\
1109(\mathrm{~m})\end{array}$ & $\begin{array}{l}512(\mathrm{~m}) \\
500(\mathrm{br})\end{array}$ & $412(\mathrm{~m})$ \\
\hline 3 & $\begin{array}{l}1562(\mathrm{w}), 1542(\mathrm{w}) \\
1537(\mathrm{~m})\end{array}$ & $1360(\mathrm{~m})$ & $848(w)$ & $\begin{array}{l}1113(\mathrm{~s}) \\
1106(\mathrm{~s})\end{array}$ & $\begin{array}{l}503(\mathrm{~m}) \\
492(\mathrm{~m})\end{array}$ & $392(\mathrm{~m})$ \\
\hline 4 & $\begin{array}{l}1565(\mathrm{w}), 1545(\mathrm{w}) \\
1538(\mathrm{~m})\end{array}$ & $1355(\mathrm{~m})$ & $848(w)$ & $\begin{array}{l}1119(\mathrm{~s}) \\
1112(\mathrm{~m})\end{array}$ & $\begin{array}{l}508(\mathrm{~m}) \\
490(\mathrm{~m})\end{array}$ & $398(\mathrm{~m})$ \\
\hline 5 & $\begin{array}{l}1572(\mathrm{w}), 1550(\mathrm{~m}) \\
1542(\mathrm{~m})\end{array}$ & $1345(\mathrm{~m})$ & $832(\mathrm{~m})$ & $\begin{array}{l}1117(\mathrm{~s}) \\
1109(\mathrm{~m})\end{array}$ & $\begin{array}{l}511(\mathrm{~m}) \\
501(\mathrm{br})\end{array}$ & $408(\mathrm{~m})$ \\
\hline 6 & $\begin{array}{l}1575(\mathrm{w}), 1550(\mathrm{~m}) \\
1545(\mathrm{~m})\end{array}$ & $1345(\mathrm{~m})$ & $873(\mathrm{~m})$ & $\begin{array}{l}1117(\mathrm{~m}) \\
1112(\mathrm{~s})\end{array}$ & $\begin{array}{l}510(\mathrm{~m}) \\
503(\mathrm{~m})\end{array}$ & $408(\mathrm{~m})$ \\
\hline 7 & $\begin{array}{l}1575(\mathrm{w}), 1550(\mathrm{~m}) \\
1545(\mathrm{~m})\end{array}$ & $1347(\mathrm{~m})$ & $872(\mathrm{~m})$ & $\begin{array}{l}1117(\mathrm{~s}) \\
1112(\mathrm{~m})\end{array}$ & $\begin{array}{l}500(\mathrm{~m}) \\
492(\mathrm{w})\end{array}$ & $413(\mathrm{~m})$ \\
\hline 8 & $\begin{array}{l}1560(\mathrm{~m}), 1554(\mathrm{w}) \\
1540(\mathrm{w})\end{array}$ & $1330(\mathrm{~m})$ & $838(\mathrm{~m})$ & $\begin{array}{l}1119(\mathrm{~m}) \\
1112(\mathrm{~s})\end{array}$ & $\begin{array}{l}522(\mathrm{~m}) \\
510(\mathrm{w})\end{array}$ & $408(\mathrm{~m})$ \\
\hline 9 & $\begin{array}{l}1560(\mathrm{~m}), 1552(\mathrm{w}) \\
1530(\mathrm{~m})\end{array}$ & $1345(\mathrm{~m})$ & $835(\mathrm{~m})$ & $\begin{array}{l}1118(\mathrm{~s}) \\
1110(\mathrm{~m})\end{array}$ & $\begin{array}{l}515(\mathrm{~m}) \\
505(\mathrm{~m})\end{array}$ & $413(\mathrm{~m})$ \\
\hline 10 & $\begin{array}{l}1562(\mathrm{~m}), 1555(\mathrm{w}) \\
1535(\mathrm{~m})\end{array}$ & $1346(\mathrm{~m})$ & $835(\mathrm{~m})$ & $\begin{array}{l}1114(\mathrm{~s}) \\
1106(\mathrm{~s})\end{array}$ & $\begin{array}{l}505(\mathrm{~m}) \\
491(\mathrm{~m})\end{array}$ & $394(\mathrm{~m}$ \\
\hline 11 & $\begin{array}{l}1562(\mathrm{~m}), 1558(\mathrm{~m}) \\
1532(\mathrm{~m})\end{array}$ & $1345(\mathrm{~m})$ & $838(\mathrm{~m})$ & $\begin{array}{l}1119(\mathrm{~s}) \\
1113(\mathrm{~m})\end{array}$ & $\begin{array}{l}507(\mathrm{~m}) \\
491(\mathrm{~m})\end{array}$ & $398(\mathrm{~m})$ \\
\hline
\end{tabular}

$\mathrm{w}=$ weak, $\mathrm{m}=$ medium, $\mathrm{s}=$ strong.

a Picric acid $(1560(\mathrm{w}), 1548(\mathrm{~m}), 1535(\mathrm{~m}))$, 2,5-dinitrophenol (1575 (m), $1555(\mathrm{~m}), 1540(\mathrm{~m}))$, and 2,4-dinitrophenol $(1578(\mathrm{~m}), 1550(\mathrm{~m}), 1537(\mathrm{w}))$.

b Picric acid, 2,6-dinitrophenol, and 2,4-dinitrophenol (1345 (s)).

c Picric acid $(835(\mathrm{w}))$, 2,6-dinitrophenol $(858(\mathrm{~m}))$, and 2,4-dinitrophenol $(842(\mathrm{~m}))$.

(a), (b), and (c) are assigned according to Ref. [12].

(d), (e), and (f) are assigned according to Ref. [13], [14] and [15] respectively.

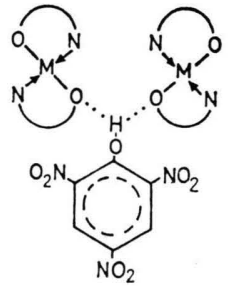

Fig. 1. Suggested association of nitrophenol with the metal oxinate in $\left(\mathrm{MOx}_{2}\right)_{2}$ nitrophenol.

the weak vibrational bands in the $1700-2000 \mathrm{~cm}^{-1}$ region which can be assigned to the hydrogen bonding system and by the splitting of the $\nu \mathrm{C}-\mathrm{O}$ and in-plane $\mathrm{C}-\mathrm{O}$ bending of the chelated oxinate. The strength of the hydrogen bond formation will control, to a large extent, the orientation of the nitrophenol between the two molecules of the metal oxinate, and in turn the possibility for the metal oxinate and the nitrophenol to manifest their donor and acceptor behaviours, respectively. The charge- transfer band observed from the red complexed obtained from the reaction of cobalt(II) oxinate

Table III. Weak vibrational bands ascribed to the hydrogen bonding system.

\begin{tabular}{rl}
\hline Complex & $\begin{array}{l}\text { Location of bands }\left[\mathrm{cm}^{-1}\right] ; \\
\text { centres of weak and broad bands }\end{array}$ \\
\hline $\mathbf{1}$ & $1940,1900,1860,1800,1730$ \\
$\mathbf{2}$ & $1960,1930,1860,1760,1730$ \\
$\mathbf{3}$ & $1965,1930,1910,1850,1770$ \\
$\mathbf{4}$ & $1950,1870,1820,1790,1730$ \\
$\mathbf{5}$ & $1960,1930,1880,1780,1740$ \\
$\mathbf{6}$ & $1950,1910,1840,1760,1730$ \\
$\mathbf{7}$ & $1970,1930,1820,1740,1720$ \\
$\mathbf{8}$ & $1940,1880,1810,1750,1730$ \\
$\mathbf{9}$ & $1950,1890,1820,1780,1710$ \\
$\mathbf{1 0}$ & $1960,1930,1860,1770,1730$ \\
$\mathbf{1 1}$ & $1950,1880,1820,1790,1730$ \\
\hline
\end{tabular}


with 2,6-dinitrophenol (compound 6) as well as with picric acid or 2,4-dinitrophenol [16] (identical stoichiometry of 2 metal oxinate: 1 nitrophenol) suggests that the nitrophenol is capable, in these cases, to react with the chelate ring (hydrogen bonding to the oxygen of two bidentate oxinate) and to accept $\pi$-electrons from the coordinated oxinate. The electronic spectra of the metal complexes in chloroform (Table IV) show absorption

Table IV. Electronic spectra of metal complexes in chloroform, and as Nujol mull.

\begin{tabular}{lll}
\hline $\begin{array}{l}\text { Metal } \\
\text { complex }\end{array}$ & \multicolumn{2}{c}{$\lambda_{\max }[\mathrm{nm}]$} \\
& Chloroform solution* & Nujol mull \\
\hline $\mathbf{1}$ & $405,332,315,257$ & 430 \\
$\mathbf{2}$ & $365,335,253$ & 400 \\
$\mathbf{3}$ & $390-365(\mathrm{sh}), 325,250$ & 405 \\
$\mathbf{4}$ & 330,243 & 400 \\
$\mathbf{5}$ & $398,318,248$ & 410 \\
$\mathbf{6}$ & 375,248 & $575-550(\mathrm{br}), 400$ \\
$\mathbf{7}$ & $365,330,250$ & 425 \\
8 & $332,315,253$ & 425 \\
$\mathbf{9}$ & $362,335,252$ & 410 \\
$\mathbf{1 0}$ & $390-363(\mathrm{sh}), 335,253$ & 390 \\
$\mathbf{1 1}$ & 335,247 & 400 \\
\hline
\end{tabular}

* All metal complexes are incompletely soluble in chloroform; sh = shoulder; br = broad.

bands characteristic of the coordinated oxinate with the expected shifts associated with the type of coordinated metal ion [17]. It is worth noting that the $460 \mathrm{~nm}$ band of the tetrahedral $\mathrm{Ni}(\mathrm{II})$ oxinate [17] is not observed for the reaction products of the metal oxinate with either picric acid, 2,6-dinitrophenol, or 2,4-dinitrophenol (compounds 2, 7, and 9, respectively). This peak is replaced by a $365 \mathrm{~nm}$ peak. The replacement of the $460 \mathrm{~nm}$ peak by a $383 \mathrm{~nm}$ peak was recently reported [18] for the chloroform solution of $\mathrm{Ni}(\mathrm{II})$ oxinate to which methanol was added; a behaviour which was explained by the transformation of the metal oxinate from the tetrahedral structure to the distorted octahedral structure of the methanolic adduct [18].

The electronic spectra of the other metal complexes are not significantly different from that of the metal oxinate. The $250 \mathrm{~nm}$ peak is ascribed to the nitrophenol. The Nujol mull spectra show typical charge transfer bands in the case of the cobalt(II) complex (compound 6 ) which was similarly observed from the reaction product of cobalt(II) oxinate with either picric acid or 2,4-dinitrophenol [16]. The other complexes show absorption bands near $400 \mathrm{~cm}^{-1}$ which can not be assigned with certainty to charge-transfer since the coordinated oxinate absorbs in this region. According to Mulliken's theory [19], charge-transfer resonance interactions produce definite perturbations of the highest filled donor orbital and the lowest vacant acceptor orbital. The energy levels of the highest filled orbitals for the metal oxinate were suggested to be much higher than in the oxine ligand [3]. It should be expected, therefore, that the metal orbitals are contributing to the charge transfer process either independently or more probably in combination with the ligand $\pi$-electrons. It is assumed, accordingly, that the hydrogen bonding system that involves the oxygen atom of the bidentate oxinate impedes the extension of the delocalised $\pi$-electrons of the chelate oxinate through the metal ion. While this argument could explain the inhibition of the donor capabilities of the metal oxinate (except cobalt(II) oxinate), the presence of three nitro groups may have some additional steric effects on the orientation of the nitrophenol [20]. This is shown by the shifts of the symmetric $v \mathrm{~N}-\mathrm{O}$ from its location [21] in the nitrophenol (see Table II). The lower stability constant of the chelate ring in the magnesium oxinate results in a stronger hydrogen bond formation between the oxygen of an oxinate and picric acid (compound 5) which together with the factors discussed above could explain the metal oxinate : picric acid 1:1 stoichiometry of this complex. The fact that a definite charge-transfer band is only observed for the cobalt(II) complexes accords with the view that the lattice packing in charge-transfer complexes is determined by the tendency to increase the charge transfer probabilities and by the stability requirements relating to the decrease in the repulsive forces created by the size and shape of the reacting molecules.

The tentatively proposed structure of these complexes is not at variance with our earlier findings regarding the reaction of nitrophenols with metal acetylacetonates [22]. It was suggested that a proton addition to an oxygen atom of the coordinated acetylacetonate precedes the cleavage of the ligand. A similar proton addition also accounted for the acid-catalyzed ligand exchange reaction in $\mathrm{Al}(\mathrm{III})$ acetylacetonate [23]. 
[1] G. Briegleb, Elektronen Donator Acceptor Komplexe, Springer-Verlag, Berlin, Heidelberg, New-York 1961.

[2] A. S. Bailey and J. R. Case, Tetrahedron 3, 113 (1958); A. S. Bailey, J. Chem. Soc. 1960, 917; A. S. Bailey, B. R. Henn, and J. Langdon, Tetrahedron 19, 161 (1963); A. S. Bailey and J. M. Evans, Chem. Ind. (London) 1964, 1425.

[3] A. S. Bailey, R. J. P. Williams, and J. D. Wright, J. Chem. Soc. 1965, 2579.

[4] B. Kamenar, C. K. Prout, and J. D. Wright, ibid. 1965, 4851.

[5] A. S. Bailey and C. K. Prout, ibid. 1965, 4867.

[6] C. K. Prout and H. M. Powell, ibid. 1965, 4882.

[7] B. Kamenar, C. K. Prout, and J. D. Wright, ibid. (A) 1966, 661.

[8] M. M. Aly and A. M. Shalaby, Monatsh. Chem., in press.

[9] R. G. W. Hollingsheed, Oxine and its Derivatives, Vol. II., Butterworths, London 1954 ; J. C. Fanning and H. B. Jonassen, J. Inorg. Nucl. Chem. 25, 29 (1963).

[10] J. Abraham and A. Corsini, Anal. Chem. 42, 1528 (1970).
[11] A. Corsini, J. Abraham, and M. Thompson, Talanta 18, 481 (1971).

[12] L. K. Dyall, Aust. J. Chem. 14, 493 (1961).

[13] R. G. Charles, H. Freiser, R. Friedel, L. E. Hilliard, and W. D. Johnston, Spectrochim. Acta 8, 1 (1956).

[14] L. E. Takett and D. T. Sawyer, Inorg. Chem. 3, 692 (1964).

[15] N. Ohkaku and K. Nakamoto, ibid. 10, 798 (1971).

[16] M. M. Aly, Inorg. Nucl. Chem. Lett., in press.

[17] K. Sone, J. Am. Chem. Soc. 75, 5207 (1953).

[18] E. Sekido and K. Kunikida, Analyt. Chim. Acta 92, 183 (1977).

[19] R. S. Mulliken, J. Am. Chem. Soc. 74, 811 (1952); R. S. Mulliken and W. B. Person, Ann. Rev. Phys. Chem. 13, 107 (1962).

[20] D. S. Brown, S. C. Wallwork, and A. Wilson, Acta Crystallogr. 17, 168 (1964).

[21] J. Trotter, Can. J. Chem. 37, 1487 (1959).

[22] M. M. Aly, I. M. Issa, and L. H. Khallil, Inorg. Nucl. Chem. Lett. 8, 505 (1972); M. M. Aly, J. Inorg. Nucl. Chem. 35, 537 (1973).

[23] K. Saito and K. Masuda, Bull. Chem. Soc. Jpn. 41, 384 (1968). 